Prepared in cooperation with the Federal Emergency Management Agency

\title{
High-Water Marks From Hurricane Sandy for Coastal Areas of Connecticut, Rhode Island, and Massachusetts, October 2012
}

Data Series 1094

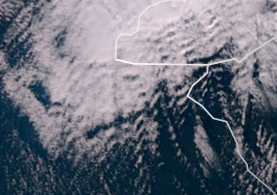

U.S. Department of the Interior U.S. Geological Survey

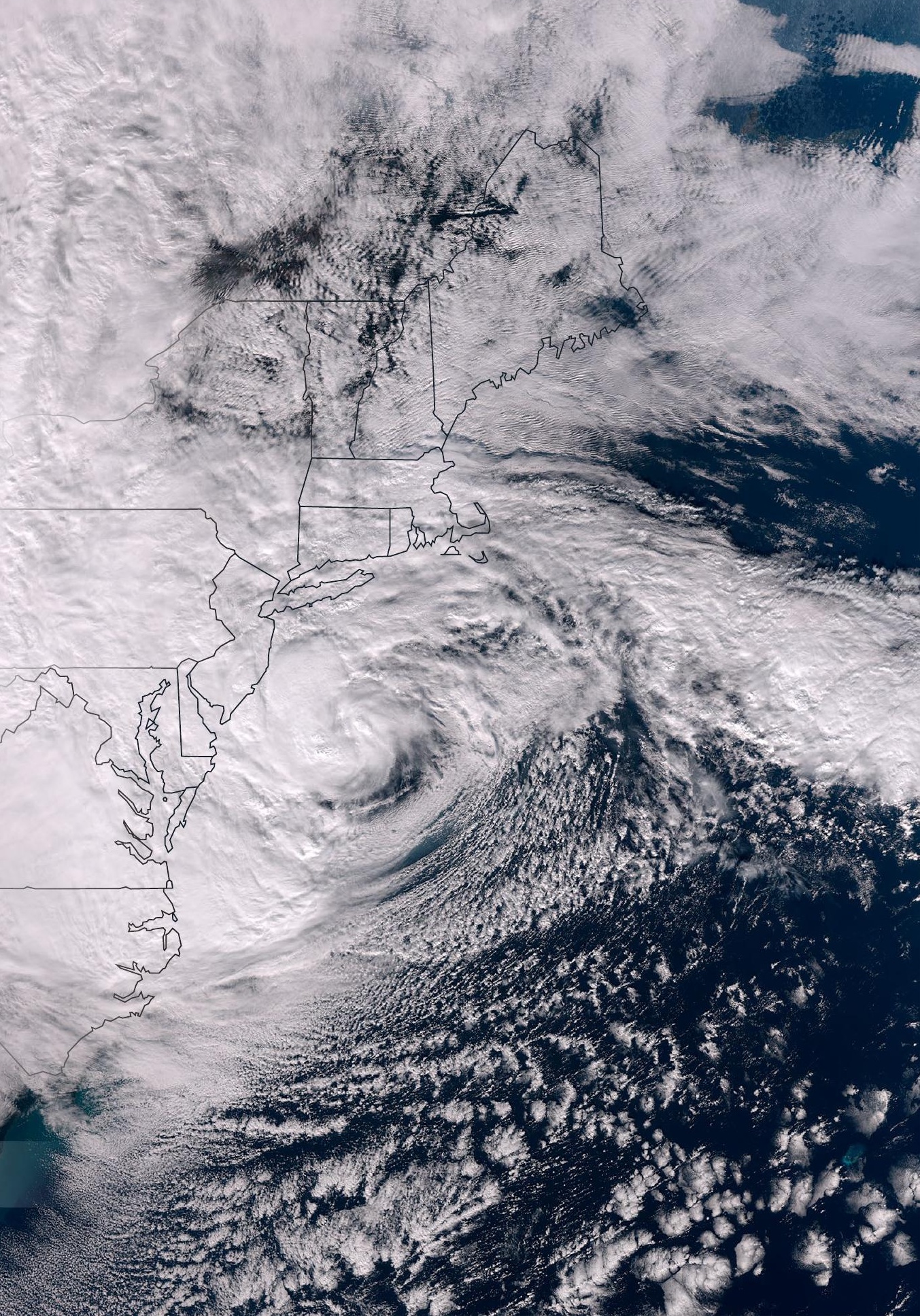


Cover. Satellite image of Hurricane Sandy over the northeastern United States on October 29, 2012, at 1735 Coordinated Universal Time (UTC; 1:35 p.m. eastern daylight time), the day the hurricane made landfall; image is from the National Aeronautics and Space Administration Earth Observatory. 


\section{High-Water Marks From Hurricane Sandy for Coastal Areas of Connecticut, Rhode Island, and Massachusetts, October 2012}

By Lance J. Ostiguy, Timothy C. Sargent, Brittney J. Izbicki, and Gardner C. Bent

Prepared in cooperation with the Federal Emergency Management Agency

Data Series 1094 


\title{
U.S. Department of the Interior \\ RYAN K. ZINKE, Secretary
}

\author{
U.S. Geological Survey \\ James F. Reilly II, Director
}

U.S. Geological Survey, Reston, Virginia: 2018

For more information on the USGS - the Federal source for science about the Earth, its natural and living resources, natural hazards, and the environment-visit https://www.usgs.gov or call 1-888-ASK-USGS.

For an overview of USGS information products, including maps, imagery, and publications,

visit https://store.usgs.gov.

Any use of trade, firm, or product names is for descriptive purposes only and does not imply endorsement by the U.S. Government.

Although this information product, for the most part, is in the public domain, it also may contain copyrighted materials as noted in the text. Permission to reproduce copyrighted items must be secured from the copyright owner.

Suggested citation:

Ostiguy, L.J., Sargent, T.C., Izbicki, B.J., and Bent, G.C., 2018, High-water marks from Hurricane Sandy for coastal areas of Connecticut, Rhode Island, and Massachusetts, October 2012: U.S. Geological Survey Data Series 1094, 16 p., https://doi.org/10.3133/ds1094.

ISSN 2327-638X (online) 


\section{Acknowledgments}

The authors wish to thank the many private home owners and businesses who allowed access to their property to identify, flag, and survey high-water marks in Connecticut, Rhode Island, and Massachusetts following Hurricane Sandy in October and November 2012, December 2013 to June 2014, and December 2016. The authors also thank the U.S. Geological Survey field personnel who identified, flagged, and surveyed high-water marks in Connecticut (Elizabeth Ahearn, David Bjerklie, Michael Columbo, Laura Flight, Timothy Frick, Jon Morrison, John Mullaney, and Robert Flynn) and in Massachusetts and Rhode Island (Roy Apostle, David Armstrong, Robert Bradley, Christopher Bruet, Dennis Claffey, Joshua Combs, Linda Comeau, Adam Hudziec, Andrew Massey, Emile Nobles, Stephen O'Brien, John O'Bryan, Michelle Ostiguy, Gene Parker, William Podolski, Lance Ramsbey, and Paul Shea). 



\section{Contents}

Acknowledgments ……...................................................................................................................

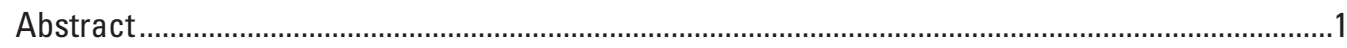

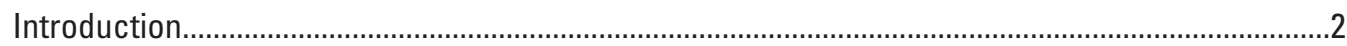

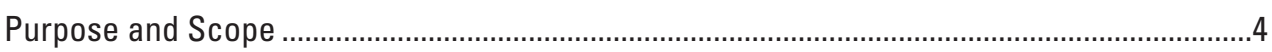

Study Area

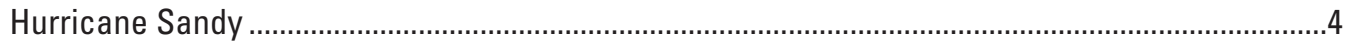

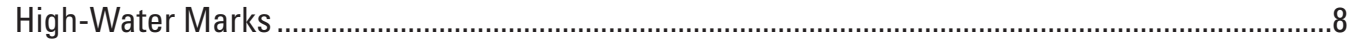

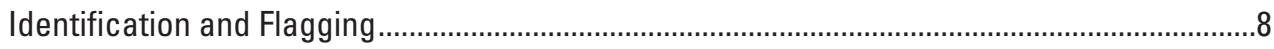

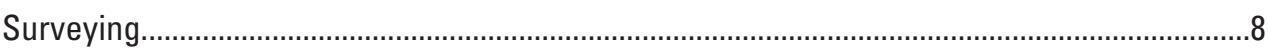

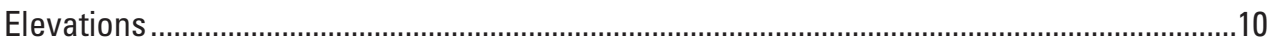

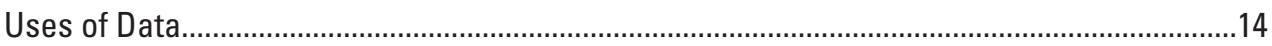

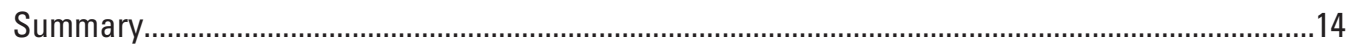

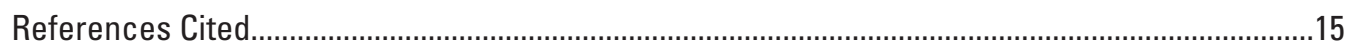

\section{Figures}

1. Map showing the path of Hurricane Sandy along the eastern coast of the United States during October 27-31, 2012

2. Maps showing locations of surveyed high-water marks associated with storm tides from Hurricane Sandy in October 2012 in coastal areas of Connecticut, Rhode Island, and Massachusetts.

3. Graphs showing water-level elevations before, during, and after Hurricane Sandy on October 28-31, 2012, at U.S. Geological Survey temporary storm tide sensors in Connecticut, Rhode Island, and Massachusetts

4. Photographs showing evidence and field methods for recording high-water marks caused by Hurricane Sandy in October 2012 in Connecticut, Rhode Island, and Massachusetts.

\section{Tables}

1. Quantitative scale to rate accuracy of high-water marks of coastal areas of Connecticut, Rhode Island, and Massachusetts.

2. Quality assurance of survey equipment used by the U.S. Geological Survey to determine positions of high-water marks from Hurricane Sandy relative to National Geodetic Survey benchmarks in and near the coastal regions of Connecticut, Rhode Island, and Massachusetts from October to December 2012, December 2013 to June 2014, and December 2016...

3. Summary of high-water marks flagged and surveyed in coastal areas of Connecticut, Rhode Island, and Massachusetts following Hurricane Sandy in October 2012 


\section{Conversion Factors}

U.S. customary units to International System of Units

\begin{tabular}{lll}
\hline \multicolumn{1}{c}{ Multiply } & \multicolumn{1}{c}{ By } & \multicolumn{1}{c}{ To obtain } \\
\hline inch (in.) & 2.54 & centimeter $(\mathrm{cm})$ \\
foot (ft) & 0.3048 & meter $(\mathrm{m})$ \\
mile (mi) & 1.609 & kilometer $(\mathrm{km})$ \\
square mile $\left(\mathrm{mi}^{2}\right)$ & 2.590 & square kilometer $\left(\mathrm{km}^{2}\right)$ \\
\hline
\end{tabular}

\section{Datum}

Vertical coordinate information is referenced to the North American Vertical Datum of 1988 (NAVD 88).

Horizontal coordinate information is referenced to the North American Datum of 1983 (NAD 83).

Elevation, as used in this report, refers to distance above the vertical datum.

\section{Abbreviations}

$\begin{array}{ll}\text { FEMA } & \text { Federal Emergency Management Agency } \\ \text { GNSS } & \text { Global Navigation Satellite System } \\ \text { GPS } & \text { Global Positioning System } \\ \text { HWM } & \text { high-water mark } \\ \text { NAD 83 } & \text { North American Datum of 1983 } \\ \text { NAVD 88 } & \text { North American Vertical Datum of 1988 } \\ \text { NGS } & \text { National Geodetic Survey } \\ \text { NHC } & \text { National Hurricane Center } \\ \text { NOAA } & \text { National Oceanic and Atmospheric Administration } \\ \text { USGS } & \text { U.S. Geological Survey }\end{array}$




\title{
High-Water Marks From Hurricane Sandy for Coastal Areas of Connecticut, Rhode Island, and Massachusetts, October 2012
}

\author{
By Lance J. Ostiguy, Timothy C. Sargent, Brittney J. Izbicki, and Gardner C. Bent
}

\section{Abstract}

Because coastal areas in Connecticut, Rhode Island, and Massachusetts were heavily affected by Hurricane Sandy in October 2012, the U.S. Geological Survey (USGS), under a mission agreement with the Federal Emergency Management Agency, collected storm tide high-water marks in those coastal areas. This effort was undertaken to better understand the areal extent and impact of storm tides resulting from strong storms.

On October 27-29, 2012, Hurricane Sandy moved up the eastern coast of the United States after passing over the Bahamas. On October 29 at about 7:30 p.m. eastern daylight time, Hurricane Sandy made landfall its final time near Brigantine, New Jersey, with recorded wind speeds of about 80 miles per hour. The damages from Hurricane Sandy exceeded $\$ 50$ billion in total, making it the second most costly Atlantic hurricane at that time, second only to Hurricane Katrina in 2005. Hurricane Sandy also resulted in 147 deaths, and about 650,000 homes and many businesses being damaged along the eastern coast of the United States. The severity of Hurricane Sandy's effects resulted in presidential disaster declarations being declared in 10 States from Virginia to Massachusetts and the District of Columbia in the months following Hurricane Sandy; the list of States affected included Connecticut, Rhode Island, and Massachusetts.

In response to the approach of Hurricane Sandy, the USGS deployed 60 temporary storm tide sensors and 2 temporary real-time rapid deployment gages to collect tide elevation data during the storm along the coastal areas of Connecticut, Rhode Island, and Massachusetts. This activity was done from Virginia to Maine before the storm. Following Hurricane Sandy, in October and November 2012, 371 storm tide high-water marks were identified and flagged in the coastal areas of Connecticut, Rhode Island, and Massachusetts. High-water marks near USGS temporary storm tide sensors, real-time rapid deployment gages, and streamgages affected by the tides as well as high-water marks on Block Island, R.I., and Martha's Vineyard and Nantucket, Mass., were surveyed at the same time the high-water marks were identified and flagged in October and November 2012. The remaining highwater marks flagged during October and November 2012 were surveyed from December 2013 through June 2014 and in December 2016. Elevations of all high-water marks were referenced to the North American Vertical Datum of 1988 and horizontal coordinates to the North American Datum of 1983 using the Global Navigation Satellite System, survey-grade Digital Global Positioning System receivers, and total station surveying equipment.

Of the 371 storm tide high-water marks flagged following Hurricane Sandy, only 364 high-water marks were surveyed; the remaining 7 could not be found or had been destroyed when locations were revisited to conduct surveys. The 157 high-water marks surveyed in Connecticut had elevations that ranged from 2.5 to 12.2 feet (ft) with an average elevation of $8.1 \mathrm{ft}$ and a median elevation of $8.3 \mathrm{ft}$. The 76 highwater marks in Rhode Island had elevations that ranged from 3.6 to $16.2 \mathrm{ft}$ and averaged $7.1 \mathrm{ft}$ with a median of $6.6 \mathrm{ft}$. The 131 high-water marks in Massachusetts had elevations that ranged from 2.8 to $22.7 \mathrm{ft}$ and averaged $7.3 \mathrm{ft}$ with a median of $6.6 \mathrm{ft}$. Individual information on the location, type, accuracy, and elevation of the 371 high-water marks can be found in an accompanying USGS data release and at the USGS Flood Event Viewer website for Hurricane Sandy (https://stn.wim.usgs.gov/fev/\#Sandy).

The high-water marks along the coast line of Connecticut and eastern Massachusetts, including Nantucket, generally had higher storm tide elevations than the coast line of Rhode Island including Block Island and southern Massachusetts, including Martha's Vineyard. The high-water mark elevations compare well with recorded peak-storm tide data at USGS temporary storm tide sensors and real-time rapid deployment gages deployed for Hurricane Sandy in Connecticut, Rhode Island, and Massachusetts.

High-water mark data collected following Hurricane Sandy will be used by Federal, State, and local government agencies, nongovernmental organizations, universities, and the public for better understanding the areal extent and impact of the storm tides. Additionally, these data can be used for such activities as land-use planning, flood risk studies, flood resiliency studies, and coastal modeling. These data from this historic storm can be compared with other regional hurricanes and tropical storms for planning into the future. 


\section{Introduction}

On Sunday, October 28, 2012, President Barack Obama declared a state of emergency for the Atlantic coastal areas of Maryland, the District of Columbia, Delaware, New York, Connecticut, and Rhode Island caused by Hurricane Sandy (fig. 1). Hurricane Sandy made landfall on Monday, October 29, 2012, at about 7:30 p.m. eastern daylight time, near Brigantine, New Jersey, but the effects of the storm surge were seen from Virginia to Maine along the Atlantic coast (National Aeronautics and Space Administration, 2013). Imagery from the National Aeronautics and Space Administration's (NASA) Aqua satellite taken on October 29, 2012, at 2:20 p.m. shows the large circular motion of the superstorm covered approximately 1.8 million square miles. With an estimated $\$ 50$ billion in damages (Blake and others, 2013), Hurricane Sandy was the second costliest Atlantic hurricane on record at that time after Hurricane Katrina, which cost an estimated \$108 billion dollars (Knabb and others, 2005). In total, 147 people lost their lives, about 650,000 homes were damaged or destroyed, and about 8.5 million customers lost power at some time because of the storm (National Aeronautics and Space Administration, 2013).

Major disaster declarations were declared for Connecticut, Delaware, the District of Columbia, Maryland, Massachusetts, New Hampshire, New Jersey, New York, Rhode Island, Virginia, and West Virginia (Federal Emergency Management Agency, 2012). In New England, most damages from Hurricane Sandy were along the southern coastal areas of Connecticut, Rhode Island, and Massachusetts, including the coastal islands of Block Island, R.I., and Martha's Vineyard and Nantucket, Mass. The Federal Emergency Management Agency (FEMA) reported that $\$ 1.4$ billion was disbursed through the Individuals and Households Program, about $\$ 15.2$ billion had been obligated through the Public Assistance Program, and about an additional $\$ 1$ billion had been awarded through the Hazard Mitigation Grant Program (Federal Emergency Management Agency, 2018).

The coastline of southern New England has not been as severely affected by a hurricane since Hurricane Bob in 1991. Tropical Storm Irene in August 2011 had only a minor effect on the coastline because it caused mainly inland riverine flooding from heavy rainfall. Before Hurricane Bob in 1991, there had been a small number of hurricanes that affected the coastline, such as the Great New England Hurricane of 1938, Hurricane Carol in 1954, and Hurricane Diana in 1955 (Massachusetts Executive Office of Public Safety and Security, 2015).

The highest recorded wind gust in Connecticut was 5 miles west of Bristol (not shown), with a wind speed of 70 miles per hour (mi/hr; National Oceanic and Atmospheric Administration, 2012b). From October 29 into early morning October 30, winds in Connecticut were regularly gusting between 40 to $70 \mathrm{mi} / \mathrm{hr}$. These high winds downed trees statewide, resulting in power outages affecting 640,000 people (National Oceanic and Atmospheric Administration, 2012b) and closed gas stations, limiting the accessibility to bring help where it was needed. The National Oceanic and Atmospheric Administration (NOAA) National Ocean Service (NOS) tide gage station BREHC3-8467150 in Bridgeport reported the highest storm tide in Connecticut at 9.30 feet (ft) above the North American Vertical Datum of 1988 (NAVD 88; National Oceanic and Atmospheric Administration, 2012a; Blake and others, 2013). Inundation from storm tide was estimated to range from 3 to $6 \mathrm{ft}$ above ground level along the coast from NOS tide gages and U.S. Geological Survey (USGS) highwater marks (HWMs) and temporary storm tide sensors. NOAA estimated the cost of property damages in Connecticut to be $\$ 2.8$ million.

In Rhode Island, a record gust of $86 \mathrm{mi} / \mathrm{hr}$ was recorded in Westerly. Inland, gusts were recorded up to $60 \mathrm{mi} / \mathrm{hr}$, causing numerous power outages (National Oceanic and Atmospheric Administration, 2012b). Along with high winds, almost the entire southern coastline was affected by moderate to severe flooding. On October 29, 2012, most of the flood waters exceeded prestorm tide levels. Although the October 29 morning high tide created only minor to moderate damage along the coast, this tide weakened the natural barriers ahead of the evening high tide. A storm surge of more than $5 \mathrm{ft}$ high and waves greater than $30 \mathrm{ft}$ tall crashed over these areas weakened from the morning tide (National Oceanic and Atmospheric Administration, 2012b). As a result, the water from the storm tide overwashed the established beaches and previously weakened areas and flowed into low elevations areas lying just inland. The force from the storm surge removed houses and coastal structures along the beach while also infiltrating coastal ponds. New breaches were formed from the surge of seawater entering and leaving the inland areas. Blake and others (2013) estimated inundation from storm tide as ranging from 3 to $5 \mathrm{ft}$ above ground level along the Rhode Island coast from NOS tide gages and USGS HWMs and temporary storm tide sensors. In terms of costs, Rhode Island's greatest damage was caused by coastal flooding. The total estimated cost of damages for Rhode Island was more than $\$ 11.3$ million (National Oceanic and Atmospheric Administration, 2012b).

Wind gusts in Massachusetts were the highest along the eastern coastline at 70 to $80 \mathrm{mi} / \mathrm{hr}$. A powerful thunderstorm inside the outer band of Hurricane Sandy resulted in even higher wind gusts of up to $90 \mathrm{mi} / \mathrm{hr}$ with a microburst on October 30, 2012, in Wareham, 1 day after the storm made landfall. The microburst had 60- to $70-\mathrm{mi} / \mathrm{hr}$ winds that were hardest felt at Swifts Beach, Pinehurst, and the marina on Onset Bay in Wareham. Approximately 100 trees fell, with some causing power line failures (National Oceanic and Atmospheric Administration, 2012b). Eyewitnesses and a survey team observed most of the tree damage was oriented north and south, confirming the direction of the downdraft 
$80^{\circ}$

$70^{\circ}$

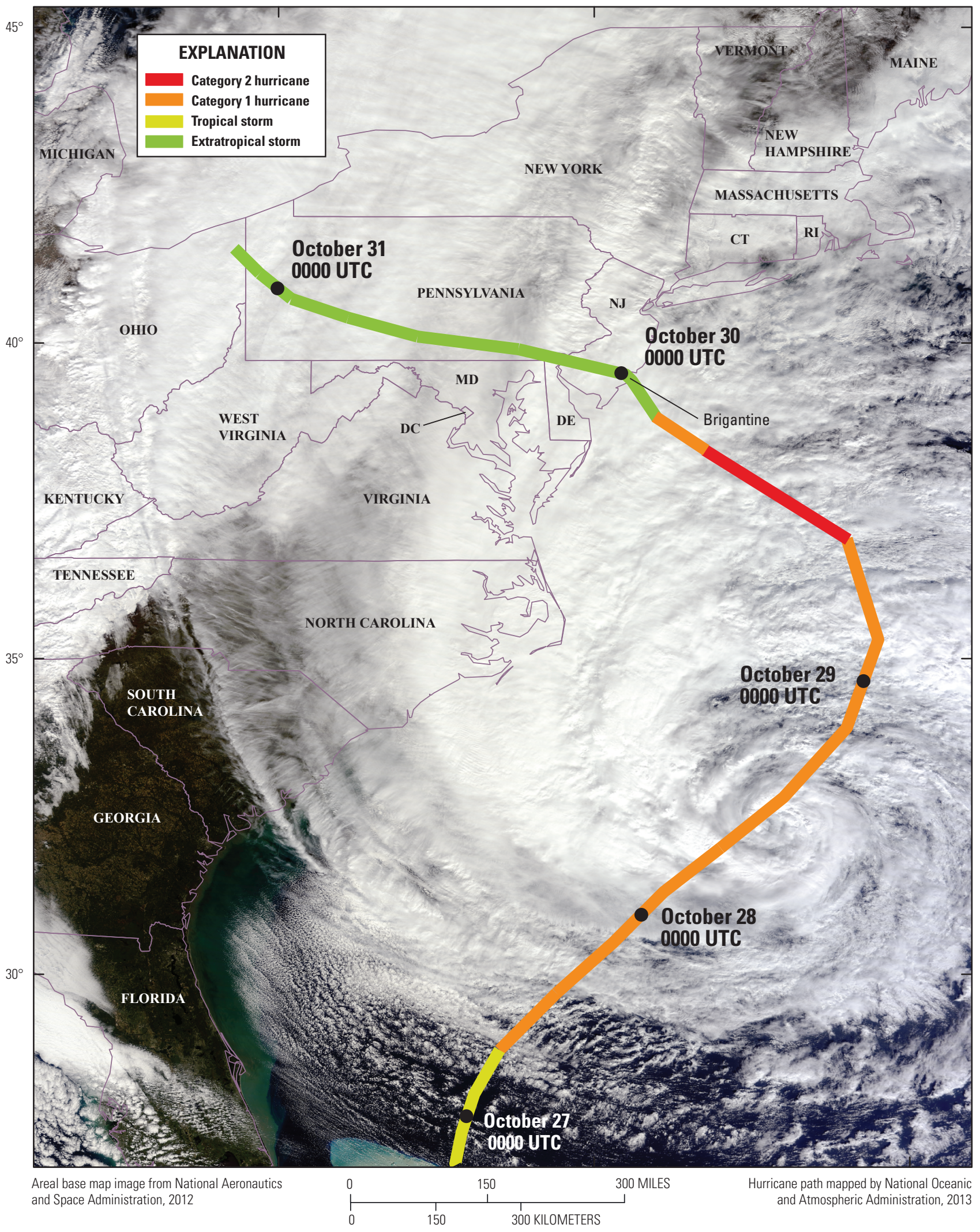

Figure 1. The path of Hurricane Sandy along the eastern coast of the United States during October 27-31, 2012. Aerial image is from October 28, 2012, at 1600 Coordinated Universal Time (UTC; 12:00 p.m. eastern daylight time). 
from the microburst. Blake and others (2013) estimated inundation from storm tide as ranging from 2 to $4 \mathrm{ft}$ above ground level along the Massachusetts coast from NOS tide gages and USGS HWMs and temporary storm tide sensors. The total estimated cost of the damages for Massachusetts was more than $\$ 20$ million (National Oceanic and Atmospheric Administration, 2012b).

In response to the approach of Hurricane Sandy, the USGS deployed a combination of 162 temporary storm tide sensors and real-time rapid deployment gages along the eastern coast of the United States from Virginia to Maine to measure the tidal elevations before (about 1 to 3 days), during, and immediately after (about 1 to 3 days) Hurricane Sandy (McCallum and others, 2013). The sites deployed included 27 sites in Connecticut, 11 sites in Rhode Island, and 23 sites in Massachusetts. The effects of storm tide from Hurricane Sandy could also be seen at 2 USGS tidal gages and streamgages (located on tidally affected rivers) in Connecticut, 1 gage in Rhode Island, and 12 gages in Massachusetts (McCallum and others, 2013, table 4). Peak storm tide elevation data collected at temporary storm tide sensors, temporary real-time rapid deployment gages, tidal gages, and streamgages (affected by the storm tide) are published in McCallum and others (2013). Additionally, storm tide data, graphs, and photographs of the continuous tide for those locations are available from the USGS Flood Event Viewer website for Hurricane Sandy (https://stn.wim.usgs.gov/ fev/\#Sandy).

\section{Purpose and Scope}

This report documents and provides data on HWMs from Hurricane Sandy on October 29, 2012, in the coastal areas of Connecticut, Rhode Island, and Massachusetts that have not been previously published to enhance understanding of the areal extent and impact of storm tides resulting from strong storms. Immediately after Hurricane Sandy, the USGS flagged and surveyed HWMs along the hardest hit coastal areas from Virginia to Massachusetts. HWMs were identified along the entire coastline of southern New England. Elevation data for HWMs were gathered at or near the temporary storm tide sensors, temporary real-time rapid deployment gages, tidal gages, and streamgages (affected by the storm tide) as well as at other selected locations (such as Block Island, Martha's Vineyard, and Nantucket) for 35 sites in Connecticut, 17 sites in Rhode Island, and 86 sites in Massachusetts (McCallum and others, 2013). HWMs at other locations were surveyed later from December 2013 to June 2014 and December 2016 and are presented in this report. The methods used to identify, flag, and survey the HWMs to vertical and horizontal datums are described. This report presents a summary of elevations for all HWMs by county, by State, and for the three States combined. Individual information on the all the HWMs are presented in Bent (2018) and are available on the USGS Flood Event Viewer website for Hurricane Sandy (https://stn.wim.usgs.gov/
fev/\#Sandy). These efforts in response to Hurricane Sandy were a coordinated Federal emergency response under the Stafford Act through a mission assignment with FEMA to collect and survey HWMs along the hardest hit coastal areas from Virginia to Massachusetts.

\section{Study Area}

HWMs were collected in the coastal areas of Connecticut, Rhode Island, and Massachusetts (fig. 2), including Block Island, Martha's Vineyard, and Nantucket. Within the three States, HWM sites were in the coastal counties of Fairfield, New Haven, Middlesex, and New London in Connecticut (fig. 2A); Washington, Kent, Providence, Bristol, and Newport in Rhode Island (fig. 2B); and Bristol, Barnstable, Dukes, Nantucket, Plymouth, Norfolk, Suffolk, and Essex in Massachusetts (fig. 2B). The calculated tidal shorelines for the three States are 685 miles (mi) for Connecticut, $597 \mathrm{mi}$ for Rhode Island, and 1,726 mi for Massachusetts.

Storm tides from tropical storms or hurricanes usually affect the southern coast of New England (Connecticut, Rhode Island, and Massachusetts). However, Hurricane Sandy also produced a backlash effect along the eastern shoreline of Massachusetts. The backlash was caused by the storm's rotating winds moving west around the storm's center and the abrupt change in moving direction of the storm from north to west, just as it came close to landfall in New Jersey.

\section{Hurricane Sandy}

A significant climatological event began off the western coast of Africa and was classified as Tropical Depression 18 by NOAA's National Hurricane Center (NHC) on October 22, 2012 (Blake and others, 2013). Only 6 hours after the NHC initial designation, winds from this storm reached the threshold of $39 \mathrm{mi} / \mathrm{hr}$ for a tropical storm designation, reclassifying the depression as Tropical Storm Sandy (National Oceanic and Atmospheric Administration, 2013). The storm track of Tropical Storm Sandy began in the Caribbean Sea south of Jamaica on October 22, and on October 24, the tropical storm had developed into a category 1 hurricane, displaying wind speeds from 74 to $95 \mathrm{mi} / \mathrm{hr}$, before making landfall near Bulls Bay, Jamaica. The storm traveled north from Jamaica, crossing over the eastern part of Cuba as a category 3 hurricane, with winds up to $115 \mathrm{mi} / \mathrm{hr}$.

On October 25, Hurricane Sandy came into contact with wind shear across the southern Bahamas, which resulted in it being downgraded to a tropical storm late on October 26 (Blake and others, 2013; National Oceanic and Atmospheric Administration, 2013). This transformation into a tropical storm did not last long; 12 hours later, on October 27, the storm regained hurricane status. On October 27 to 29, Hurricane Sandy traveled in a northerly direction from the 


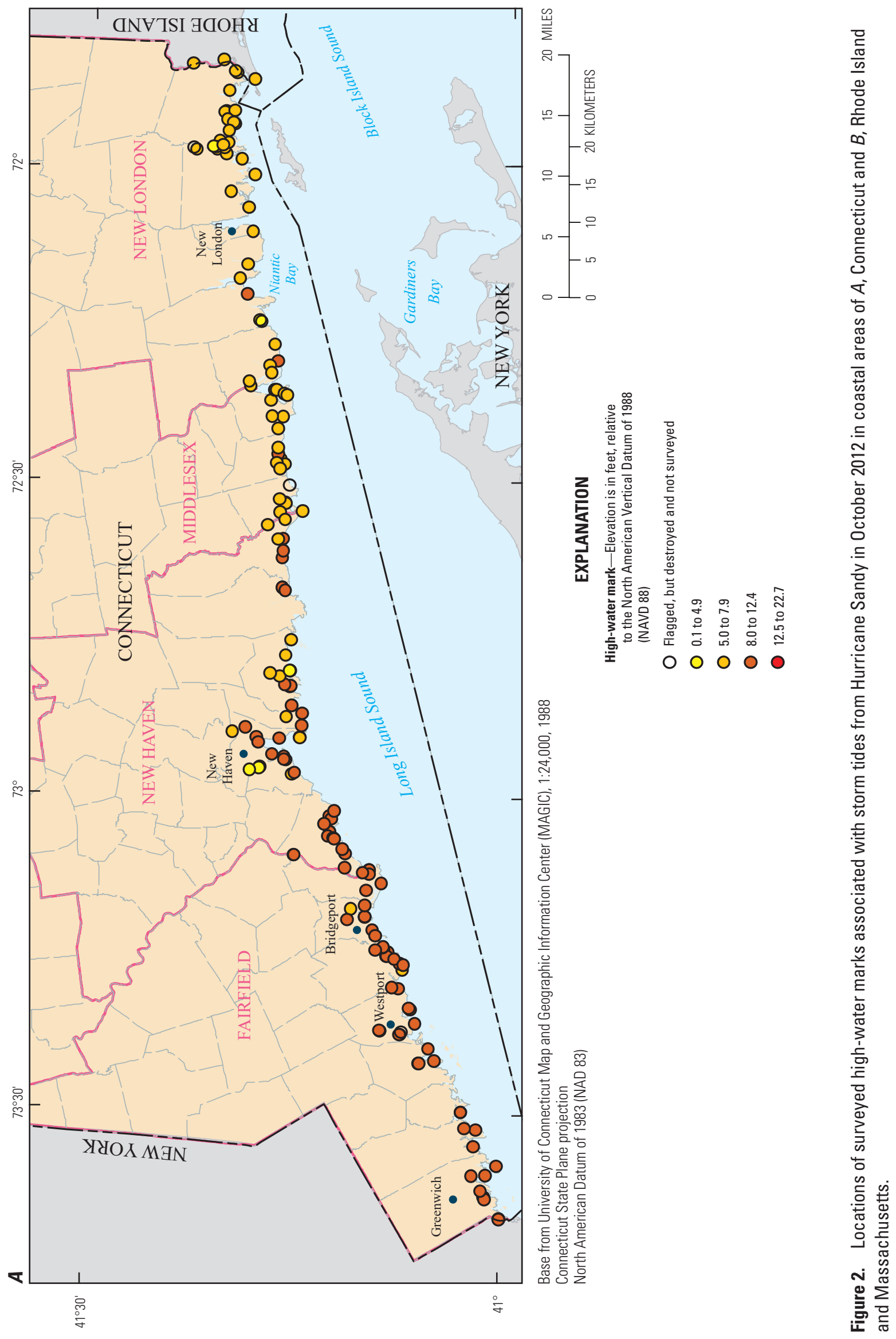




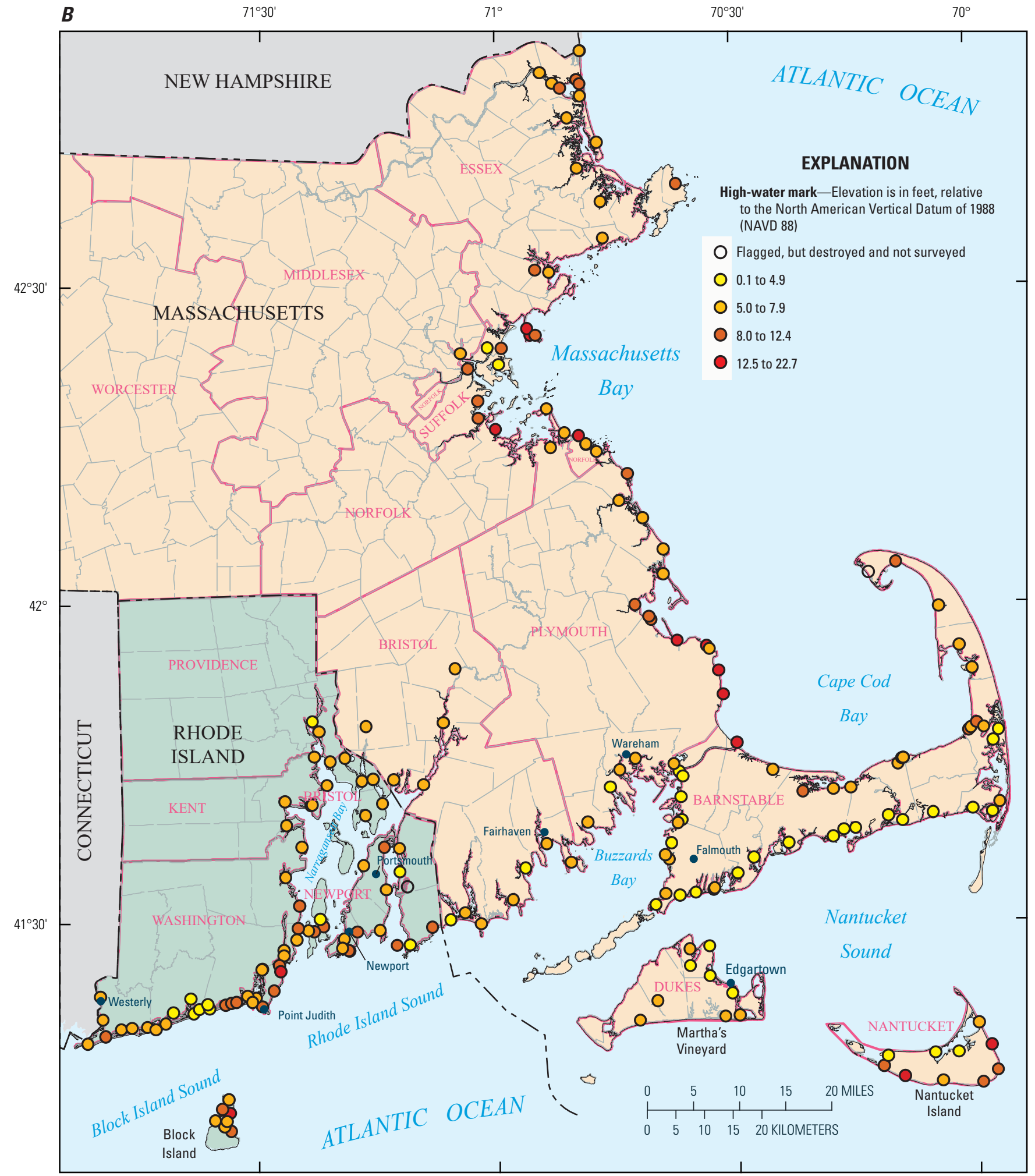

Base from Massachusetts Office of Geographic Information (MassGIS), 1:25,000

Massachusetts State Plane projection

North American Datum of 1983 (NAD 83)

Figure 2. Locations of surveyed high-water marks associated with storm tides from Hurricane Sandy in 0ctober 2012 in coastal areas of $A$, Connecticut and $B$, Rhode Island and Massachusetts.-Continued 
Bahamas along the eastern coast of the United States between Florida and Virginia, a few hundred miles off the coast (fig. 1). On October 29, Hurricane Sandy began a direct northwestern approach toward land, and around 7:30 p.m. eastern daylight time, the center of the hurricane made landfall near Brigantine, New Jersey. At this time, wind speeds were recorded near $80 \mathrm{mi} / \mathrm{hr}$ with one of the lowest recorded pressures of 945 millibars. All-time low pressures were also recorded in Philadelphia and Harrisburg, Pennsylvania, and in Baltimore, Maryland (not shown). The storm winds reached out 1,000 mi, the largest Atlantic tropical storm ever recorded. At times, wind gusts of more than $60 \mathrm{mi} / \mathrm{hr}$ were recorded as far away as the Midwest until October 31 (National Oceanic and Atmospheric Administration, 2013).

Astronomical high tides in harmony with the timing of Hurricane Sandy making landfall created the conditions needed for record-setting high tides for the year (National Oceanic and Atmospheric Administration, 2013). Storm surge or the rise in sea level above average heights along the coasts of Connecticut, Rhode Island, and Massachusetts was varied, but there was a clear difference of a few feet between the prestorm high and low tide and the tides affected by Hurricane Sandy. At New Haven, Conn., the high tide during Hurricane Sandy was recorded to be about 3 to $4 \mathrm{ft}$ higher than the prestorm high tides on October 28 at 1:00 p.m. eastern daylight time and on October 29 at about 2:00 a.m. (fig. 3A). This record was approximately $150 \mathrm{mi}$ away from the center of Hurricane Sandy along the southern coast of New England. At Point Judith, R.I., the high tide during Hurricane Sandy was about $3 \mathrm{ft}$ higher than the prestorm high tides recorded around October 28 at 11:00 a.m. and on October 29 at about 12:00 a.m. (fig. 3B). This record was approximately $200 \mathrm{mi}$ away from the center of Hurricane Sandy along the southern coast of New England. In Fairhaven, Mass., 250 mi away from the center of Hurricane Sandy, high tide was about 2 to $2.5 \mathrm{ft}$ higher than the prestorm high tide recorded around October 28 at 11:00 a.m. and on October 29 at about 12:00 a.m. (fig. 3C).

In advance of Hurricane Sandy, the USGS deployed 59 temporary storm tide sensors and 2 real-time rapid deployment gages along the coastline in Connecticut, Rhode Island, and Massachusetts (U.S. Geological Survey, 2018). The 26 temporary storm tide sensors ( 1 of the 27 sensors could not be found after the storm or was destroyed) along the coastline of Connecticut had peak tide elevations that ranged from about 5.8 to $11.7 \mathrm{ft}$ with an average of $8.3 \mathrm{ft}$ and a median of $8.3 \mathrm{ft}$. Along the coastline of Rhode Island, the 10 temporary storm tide sensors and 1 rapid deployment gage had peak tide elevations that ranged from about 4.0 to $8.4 \mathrm{ft}$ with an average of $6.3 \mathrm{ft}$ and a median of $6.4 \mathrm{ft}$. Along the coastline of Massachusetts, the 22 USGS temporary storm tide sensors and 1 rapid deployment gage had peak tide elevations that ranged from about 3.4 to $8.3 \mathrm{ft}$ with an average of $6.2 \mathrm{ft}$ and a median of $6.8 \mathrm{ft}$.
A. SSS-CT-NHV-019WL

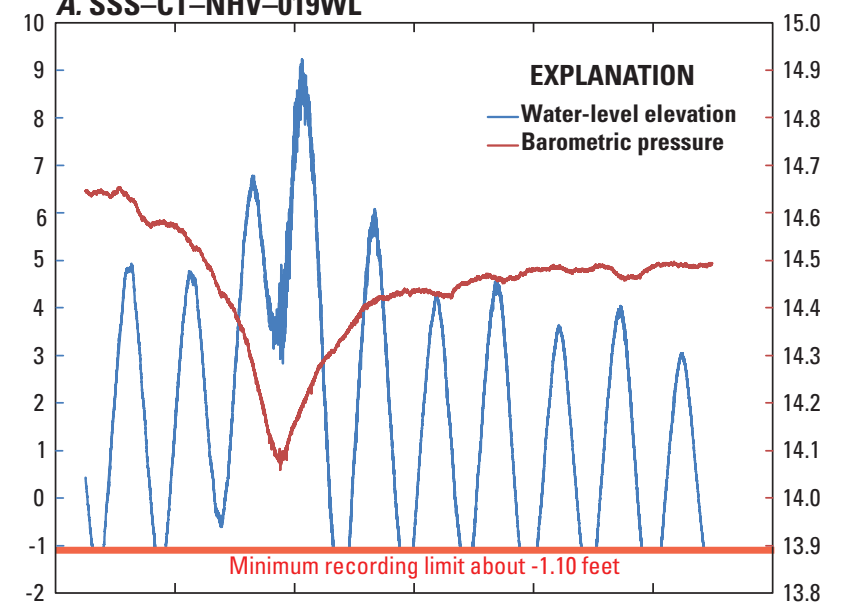

\section{.}

B. SSS-RI-WAS-008WL

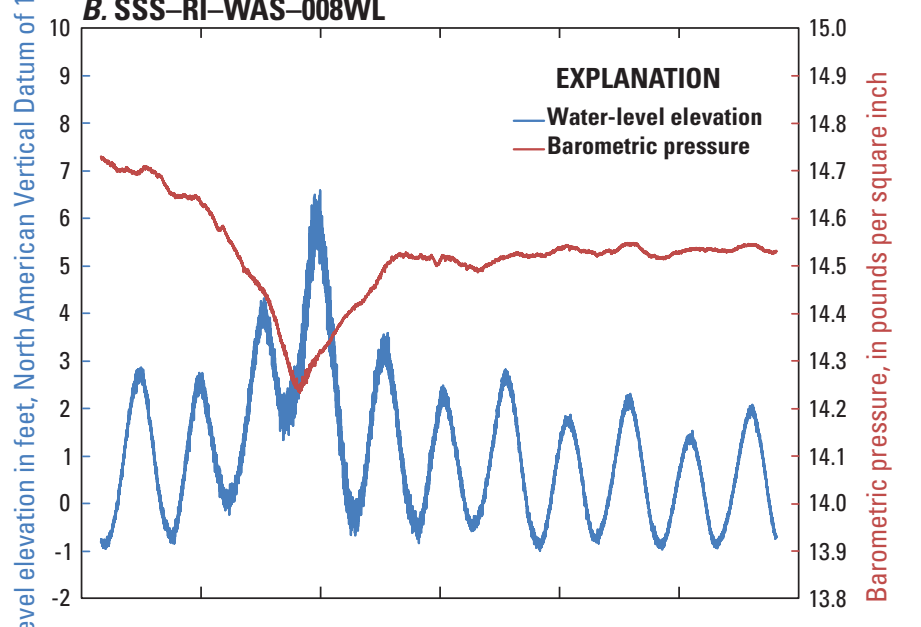

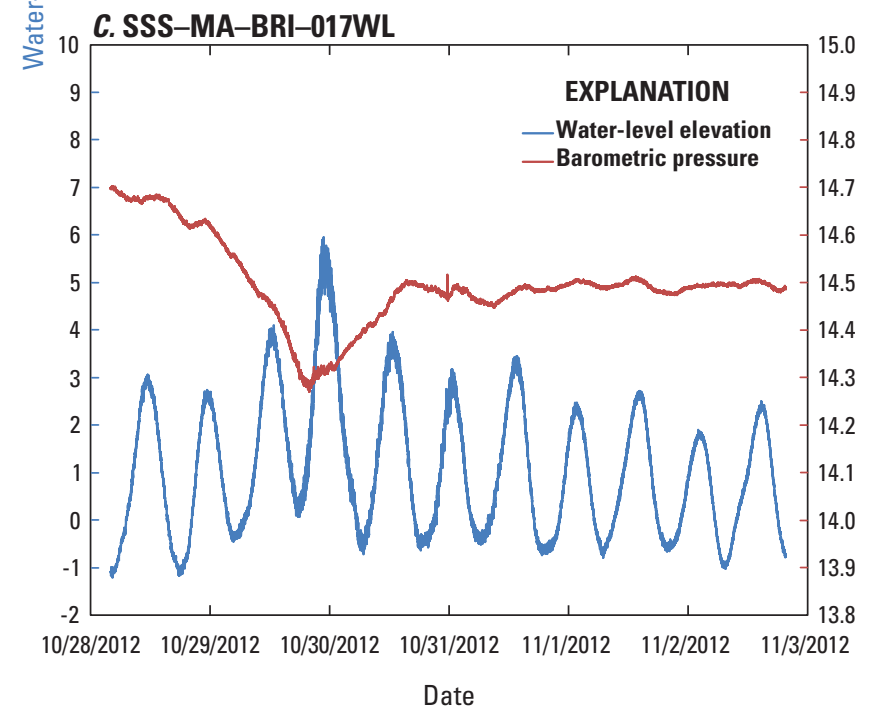

Figure 3. Water-level elevations before, during, and after Hurricane Sandy on October 28-31, 2012, at U.S. Geological Survey temporary storm tide sensors at $A$, the New Haven Coast Guard station dock at New Haven, Conn. (station SSS-CT-NHV019WL), B, Skip's Dock at Point Judith, R.I. (station SSS-RI-WAS008WL), and $C$, Hoppy's Landing at West Island, Fairhaven, Mass. (station SSS-MA-BRI-017WL). 


\section{High-Water Marks}

Evidence of the highest water surface elevation during a flood or coastal storm tide is known as a HWM (Benson and Dalrymple, 1967). The highest water level is often documented by deposits of natural and unnatural pieces of debris (seeds, grass, tree needles, leaves, woody material, sediment, or trash) that are transported by floodwaters or waves and deposited on the sides of buildings, fences, mailboxes, telephone poles, and trees. These types of deposits are common and are used as evidence in identifying the highest water level (fig. 4). After the peak flood event, the water recedes, leaving a deposit in the form of a mark. These HWMs are made when floating matter or liquid stains rest on a surface from gravity or adhesion. Well-defined HWMs form best in areas of slow water movement. It is necessary to obtain the location of HWMs as soon as the peak water levels begin to recede. Time is of the essence to find the best available HWMs at each site before the marks are faded, lost, moved, removed, or covered up by natural (rain, wind, and sun) and anthropogenic alterations. Using procedures described by Benson and Dalrymple (1967), HWMs were identified, flagged, and documented for the peak water levels from Hurricane Sandy. Information on the approximate horizontal location, the type and general accuracy of the HWM, and approximate elevations of above the land surface were documented so they could be found by surveyors later. Additionally, a sketch map was drawn and photographs were taken.

\section{Identification and Flagging}

In preparation of surveying and flagging HWMs following the peak storm tides of Hurricane Sandy, potential HWM locations were selected to provide a uniform dispersion of sites with equal distances from the next closest site as much as possible. Generally, two-person crews went into the field to identify and flag HWMs along the coastlines of the ocean and bays of Connecticut, Rhode Island, and Massachusetts in late October and between November 1 and 20, 2012. Where situations prohibited the discovery of HWMs with acceptable quality at a planned site, a nearby site of better quality was selected and identified by the field crew.

Once an adequate HWM was found, the field crew used a standard field form to record each mark with a unique identification name following the form "HWM-[two letter State abbreviation]-[three letter county abbreviation]-[field crew team number and consecutive numbering for each HWM]"(these unique identification names were for the use by the USGS New England Water Science Center), the road location, a location description of the HWM, the physical condition of the HWM, the distance of the HWM above ground surface or other described object, a qualitative description of the accuracy of the HWM, and what device was used to flag the location. The field person was given a quantitative scale — excellent, good, fair, and poor - for rating the general accuracy of the HWM (table 1).

Depending on the location of the HWM found, the field personnel could decide to flag using one or more of the following: standard USGS high water plastic disk, paint, permanent marker, nail, PK nail, chiseled mark, stake or surveyor's hub, or any other device in combination with the previously mentioned devices. Photographs of the HWMs (fig. 4) and the pathways to the HWM were taken; photographs of the surrounding area were also taken if needed. To provide additional guidance for relocating the general area where the HWMs could be rediscovered at a later date, the coordinate obtained by a simple handheld Global Positioning System (GPS) device of general accuracy was recorded on the field form of the field crew.

Field crews identified and flagged a total of $371 \mathrm{HWMs}$ in the three states of which 162 sites were located in Connecticut, 77 sites in Rhode Island, and 132 sites in Massachusetts (fig. 2). Information on the location, quality rating, type, approximate elevation above the ground surface, and data flagged of the 371 HWMs is available in a USGS data release by Bent (2018) and on the USGS Flood Event Viewer (https://stn.wim.usgs.gov/fev/\#Sandy).

Table 1. Quantitative scale to rate accuracy of high-water marks of coastal areas of Connecticut, Rhode Island, and Massachusetts.

[ft, foot; >, greater than]

\begin{tabular}{lcc}
\hline Rating & $\begin{array}{c}\text { Coastal storm surge } \\
\text { accuracy, } \\
\text { in } \mathrm{ft}^{1}\end{array}$ & $\begin{array}{c}\text { Upland riverine } \\
\text { accuracy, } \\
\text { in } \mathrm{ft}^{2}\end{array}$ \\
\hline Excellent & 0.05 & 0.02 \\
Good & 0.1 & 0.05 \\
Fair & 0.2 & 0.1 \\
Poor & 0.4 & 0.2 \\
Very poor & $>0.4$ & $>0.2$ \\
\hline
\end{tabular}

${ }^{1}$ Data are from Rydlund and Densome (2012).

${ }^{2}$ Data are from Lumia and others (1987).

\section{Surveying}

After identifying and flagging the HWMs, elevations and locations were surveyed using methods described by Rydlund and Densmore (2012). The coastal storm tide accuracy method (table 1) was used to rate the quality of the HWM (Rydlund and Densmore, 2012), because it has accuracy ranges that are twice that of the accuracies of the upland riverine method (Lumia and others, 1987). The Global Navigation Satellite System (GNSS) was used as the satellite system to help locate and establish HWM positions. A survey-grade GPS receiver 


\section{A. HWM-CT-FFD-121}

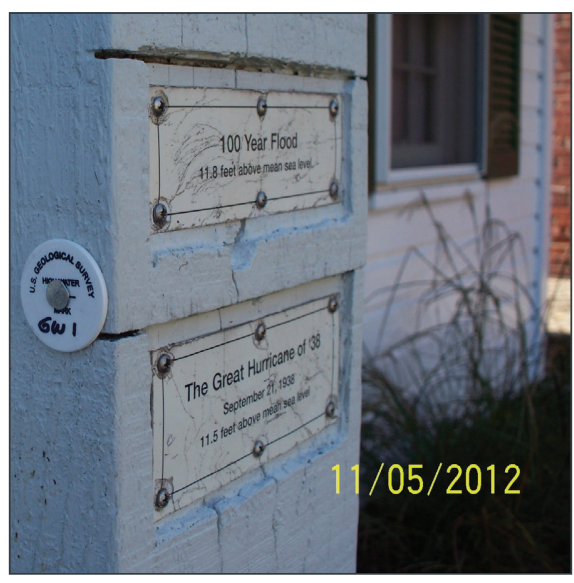

C. HWM-RI-NEW-214

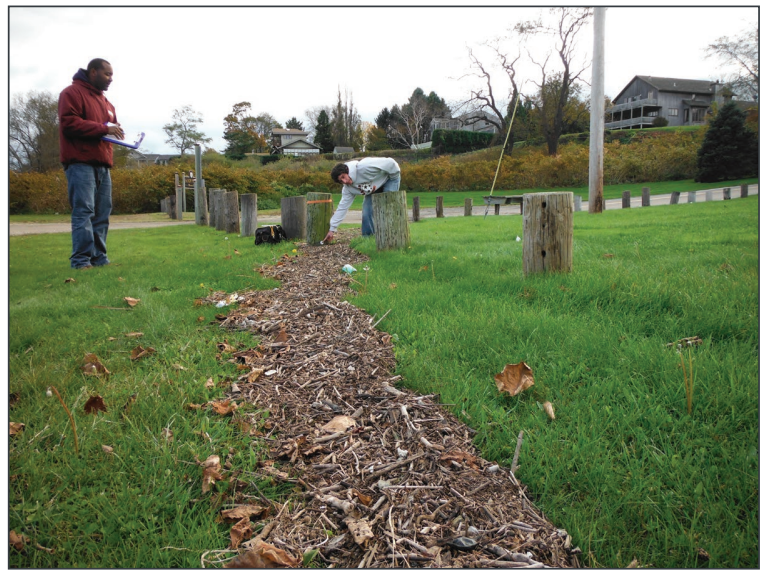

E. HWM-MA-DUK-251

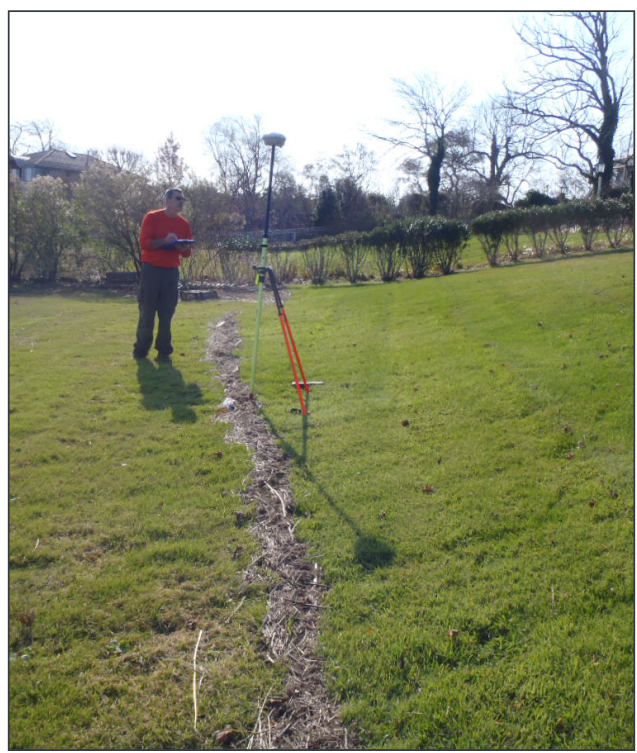

B. HWM-CT-FFD-515

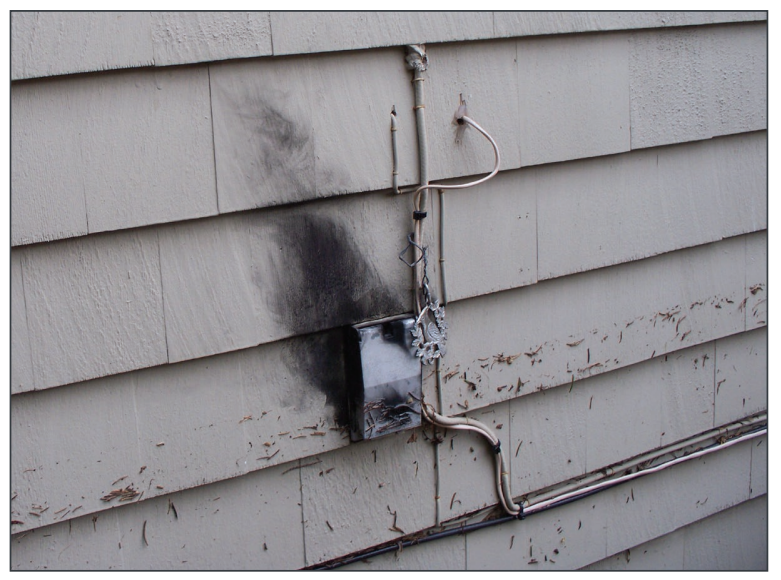

D. HWM-RI-WAS-231

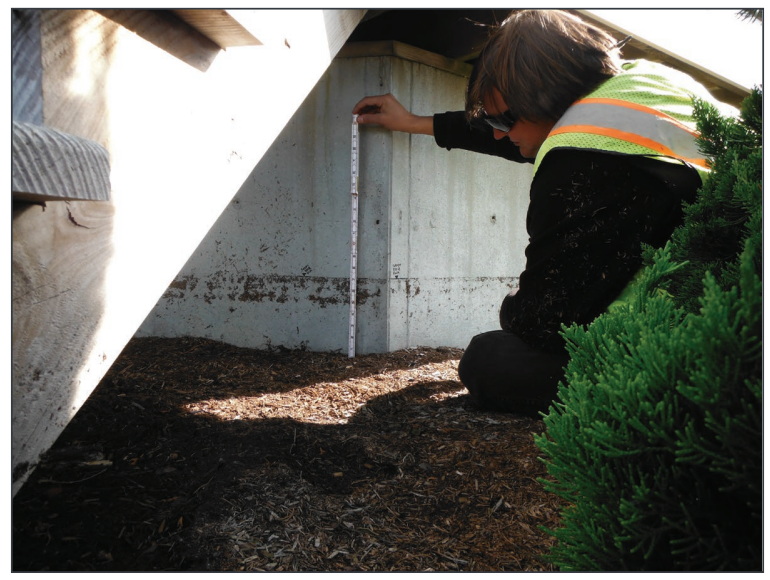

F. HWM-MA-BAR-611

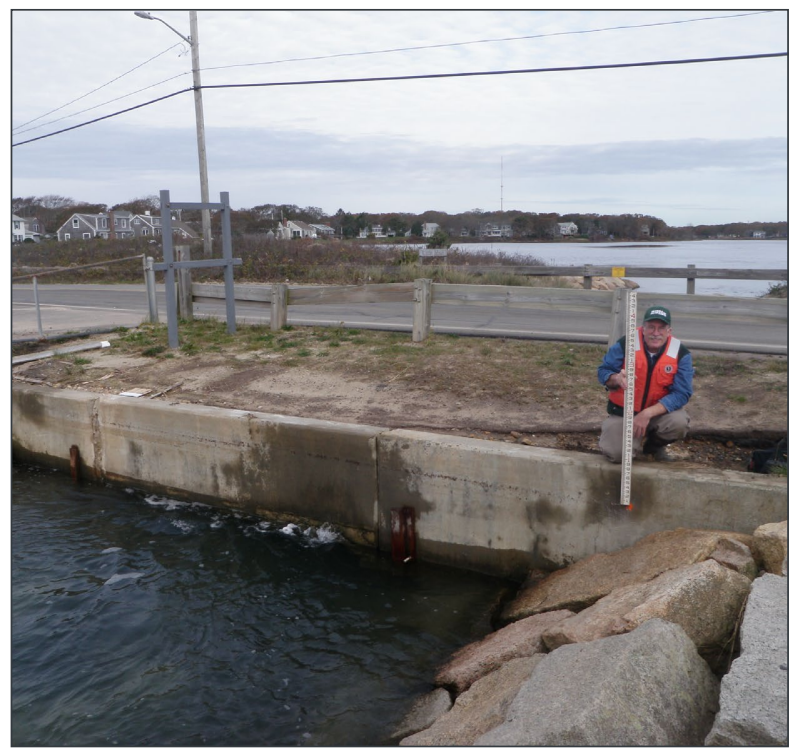

Figure 4. Evidence and field methods for recording high-water marks caused by Hurricane Sandy in Connecticut, Rhode Island, and Massachusetts. $A$, white disc nailed at location of debris line (Greenwich, Conn.); $B$, debris line found along wall siding (Westport, Conn.); $C$, white disc nailed to wooden post at a wrack line (Portsmouth, R.I.); $D$, debris line on foundation of building (Westerly, R.I.); E, creating a direct Global Positioning System record at a wrack line found on a cut lawn (Edgartown, Mass.); and $F$, stainless steel stud marking a seed line on a culvert wall (Falmouth, Mass.). 
recorded the horizontal positions of each HWM in State Plane Coordinate System and North American Datum of 1983 (NAD 83) and the control elevation in NAVD 88. The unit of measure for both the horizontal and vertical dimensions was in feet.

Photographs taken during the time of flagging were proven to be indispensable for revisiting lost or removed HWMs when the sites were resurveyed from December 2013 to June 2014 and in December 2016. Several sites were destroyed, but their exact locations were found from the information in the photographs. In these cases, the ground level or the location where a height above the ground or other object recorded in the field notes was used to add or subtract from the surveyed point. Of the $371 \mathrm{HWMs}$ identified and flagged, 7 HWMs were not surveyed because they could not be found or had been destroyed. Of the seven HWMs not surveyed, five were in Connecticut, one was in Rhode Island, and one was in Massachusetts (Bent, 2018).

In some situations, the GPS receiver could not be placed exactly on the HWM because of the physical conditions surrounding the flagged object. In these cases, the GPS receiver was offset from the actual location, usually less than 3 feet, and a bubble level was extended from the mark to the GPS receiver; the vertical difference in elevation between the HWM elevation and the GPS receiver was then used to adjust the final elevation up or down, as needed.

Trimble R8 GNSS receivers were used for each survey. Two independent measurements of the HWM elevation were made using the GPS receiver and then averaged. If the two measured elevations differed by more than $0.1 \mathrm{ft}$, then subsequent measurements were made to get at least two elevations that were within $0.1 \mathrm{ft}$ of each other. At times, satisfactory measurements of elevation could not be made. Return visits to the same site hours or days later provided an acceptable elevation when receiver reception and performance increased to a point where the error of the accuracy was less than $0.1 \mathrm{ft}$.

A network of continuous real-time differential corrected sites was provided by a fixed-base GPS network of sites under the operation of KeyNetGPS, Inc. (2013). The measurement accuracy of the GPS elevations was checked by comparing GPS readings at primarily National Geodetic Survey (NGS) benchmarks with established NAVD elevations near the coasts of Connecticut, Rhode Island, and Massachusetts during October to December 2012, December 2013 to June 2014, and December 2016 (table 2). The accuracies of the NAVD 88 elevations were checked by making GPS measurements at 26 established NGS benchmark sites (National Oceanic and Atmospheric Administration, 2012c) and 1 other benchmark site (Guilford BM 4445). The differences between the NAVD 88 and surveyed GPS elevations for 49 observations (excludes benchmark permanent identification LW0009, Dukes County, Mass., which is not NAVD 88 elevation) ranged from -0.56 to $0.49 \mathrm{ft}$, and the absolute differences had an average of $0.15 \mathrm{ft}$, a median of $0.13 \mathrm{ft}$, and a root mean squared error of $0.1884 \mathrm{ft}$ (table 2).

\section{Elevations}

The Hurricane Sandy storm tide elevations for the 364 HWMs surveyed ranged from 2.5 to $22.70 \mathrm{ft}$ above NAVD 88 along the coastline of Connecticut, Rhode Island, and Massachusetts (fig. 2; table 3). The 157 HWMs surveyed in Connecticut had elevations that ranged from 2.5 to $12.2 \mathrm{ft}$, with an average of $8.1 \mathrm{ft}$ and a median of $8.3 \mathrm{ft}$. The 76 HWMs surveyed in Rhode Island had elevations that ranged from 3.6 to $16.2 \mathrm{ft}$, with an average of $7.1 \mathrm{ft}$ and a median of $6.6 \mathrm{ft}$. The $131 \mathrm{HWMs}$ in Massachusetts had elevations that ranged from 2.8 to $22.7 \mathrm{ft}$, with an average of $7.3 \mathrm{ft}$ and a median of $6.6 \mathrm{ft}$. The storm tide elevations of the individual 364 HWMs are available in Bent (2018) and on the USGS Flood Event Viewer website for Hurricane Sandy (https://stn.wim.usgs.gov/fev/\#Sandy).

The HWM storm tide elevations (fig. 2; table 3) show a wide range, but with some general trends from west to east along the coastal areas of Connecticut, Rhode Island, and Massachusetts. The variability in the elevations is the result of the locations of the HWMs identified being in open areas on beaches, in protected areas in a harbor, or some distance inland on a coastal salt pond, on land, or in an estuary. Thus, HWM locations experience different effects from wave action or wave run up in an open area or a gentler storm tide rise in the pond, river, or storm surge inland. Some HWMs were in harbors or coastal salt ponds that were more exposed to the wind and wave direction of Hurricane Sandy. All these factors and others contribute to the variability in the observed HWM elevations.

The coastline of Connecticut generally experienced a gradual increase in storm tide elevations from east to west (fig. 2A). The median elevations of HWMs were 5.9, 7.1, 8.6, and $9.9 \mathrm{ft}$ in New London, Middlesex, New Haven, and Fairfield Counties, respectively, going from east to west (table 3).

In Rhode Island (fig. 2B) HWM elevations were varied across the State, but the higher elevations tended to be in the exposed coastal areas, such as Block Island. The median HWM elevations of the five counties of Rhode Island were very similar (table 3 ), but the average elevation and maximum elevation were highest in Washington and Newport Counties, which are the most exposed to the Atlantic Ocean.

In Massachusetts, HWM elevations varied, but were noticeably lower along the western side of Cape Cod in Buzzards Bay (shielded by land) and the southern coast of Cape Cod (somewhat shielded by Martha's Vineyard and Nantucket) than at other coastal areas (fig. 2B). This is evident in the median HWM elevations for Bristol and Barnstable Counties (table 3), which are lower than the other counties in Massachusetts. Martha's Vineyard (Dukes County) had a lower median HWM elevation (5.0 ft) similar to Bristol and Barnstable Counties. This is likely because most of the HWMs were slightly inland and not on the exposed beach areas. On Nantucket, the median HWM elevation was the highest $(9.1 \mathrm{ft})$ of the nine counties where HWMs were surveyed in Massachusetts. 
Table 2. Quality assurance of survey equipment used by the U.S. Geological Survey to determine positions of high-water marks from Hurricane Sandy relative to National Geodetic Survey benchmarks in and near the coastal regions of Connecticut, Rhode Island, and Massachusetts from October to December 2012, December 2013 to June 2014, and December 2016.

[NGS, National Geodetic Survey; PID, permanent identification; NAD 83, North American Datum of 1983; NAVD 88, North American Vertical Datum of 1988; $\mathrm{ft}$, foot; - , no data]

\begin{tabular}{|c|c|c|c|c|c|c|c|c|c|}
\hline \multirow[b]{2}{*}{ Date } & \multicolumn{2}{|l|}{ NGS benchmark } & \multirow[b]{2}{*}{ County } & \multirow[b]{2}{*}{ State } & \multicolumn{2}{|c|}{ Surveyed, in NAD $83^{2}$} & \multirow{2}{*}{$\begin{array}{c}\text { Surveyed } \\
\text { elevation, } \\
\text { in } \mathrm{ft} \text { above } \\
\text { NAVD } 88\end{array}$} & \multirow{2}{*}{$\begin{array}{c}\text { NGS } \\
\text { benchmark, } \\
\text { NAVD } 88 \\
\text { adjusted } \\
\text { elevation, } \\
{\text { in } \mathrm{ft}^{1}}^{1}\end{array}$} & \multirow{2}{*}{$\begin{array}{c}\text { Difference } \\
\text { between } \\
\text { NGS and } \\
\text { surveyed } \\
\text { elevations, } \\
\text { in } \mathrm{ft}\end{array}$} \\
\hline & $\begin{array}{c}\text { Designation } \\
\text { (stamped name) }\end{array}$ & PID & & & $\begin{array}{l}\text { Latitude, } \\
\text { in decimal } \\
\text { degrees }\end{array}$ & $\begin{array}{c}\text { Longitude, } \\
\text { in decimal } \\
\text { degrees }\end{array}$ & & & \\
\hline $10 / 31 / 2012$ & Guilford BM $4445^{3}$ & - & New Haven & Conn. & 41.27173 & -72.66509 & 6.00 & 5.96 & -0.04 \\
\hline $11 / 1 / 2012$ & G 36 & LX0434 & New Haven & Conn. & 41.28033 & -72.68560 & 19.09 & 18.85 & -0.24 \\
\hline $11 / 1 / 2012$ & Guilford BM $4445^{3}$ & - & New Haven & Conn. & 41.27173 & -72.66509 & 5.94 & 5.96 & 0.02 \\
\hline $11 / 1 / 2012$ & C 35 & MY0361 & Essex & Mass. & 42.71424 & -71.12026 & 158.76 & 158.85 & 0.09 \\
\hline $11 / 1 / 2012$ & B $84 \mathrm{C}$ & MY6017 & Middlesex & Mass. & 42.48942 & -71.17812 & 257.38 & 256.89 & -0.49 \\
\hline $11 / 2 / 2012$ & B $84 \mathrm{C}$ & MY6017 & Middlesex & Mass. & 42.48942 & -71.17812 & 257.45 & 256.89 & -0.56 \\
\hline $11 / 2 / 2012$ & GOVT & AA7161 & Plymouth & Mass. & 42.23884 & -70.78909 & 9.19 & 9.00 & -0.19 \\
\hline $11 / 2 / 2012$ & GOVT & AA7161 & Plymouth & Mass. & 42.23884 & -70.78909 & 9.23 & 9.00 & -0.23 \\
\hline $11 / 3 / 2012$ & W 35 & LX0119 & New London & Conn. & 41.29389 & -72.26556 & 65.80 & 65.78 & -0.02 \\
\hline $11 / 3 / 2012$ & 8450768 TIDAL 1 & LW0620 & Newport & R.I. & 41.46537 & -71.19186 & 6.04 & 5.99 & -0.05 \\
\hline $11 / 3 / 2012$ & X 43 & LW1510 & Plymouth & Mass. & 41.76771 & -70.72273 & 21.22 & 21.46 & 0.24 \\
\hline $11 / 5 / 2012$ & $438 \mathrm{~L}$ & AJ4044 & Barnstable & Mass. & 41.76141 & -70.59266 & 43.51 & 44.00 & 0.49 \\
\hline $11 / 5 / 2012$ & W 56 & AB7938 & Barnstable & Mass. & 41.65146 & -70.27982 & 14.90 & 15.00 & 0.10 \\
\hline $11 / 5 / 2012$ & H 48 & LW1557 & Barnstable & Mass. & 41.69541 & -70.61882 & 12.81 & 13.03 & 0.22 \\
\hline $11 / 11 / 2012$ & $\mathrm{NO}^{4}$ & LW0009 & Dukes & Mass. & 41.45686 & -70.55615 & 13.48 & 14.85 & 1.37 \\
\hline $11 / 13 / 2012$ & W 56 & AB7938 & Barnstable & Mass. & 41.65147 & -70.27982 & 14.91 & 15.00 & 0.09 \\
\hline $11 / 14 / 2012$ & $8449130 \mathrm{~K}$ TIDAL & AJ4032 & Nantucket & Mass. & 41.28925 & -70.09272 & 2.88 & 3.00 & 0.12 \\
\hline $11 / 14 / 2012$ & $31 \mathrm{D}$ & AJ4075 & Nantucket & Mass. & 41.27124 & -70.08831 & 20.74 & 21.00 & 0.26 \\
\hline $11 / 15 / 2012$ & CHATHAM LIGHT USCG & AB2629 & Barnstable & Mass. & 41.67174 & -69.94916 & 40.08 & 40.30 & 0.22 \\
\hline $11 / 15 / 2012$ & W 56 & AB7938 & Barnstable & Mass. & 41.65146 & -70.27982 & 14.92 & 15.00 & 0.08 \\
\hline $11 / 16 / 2012$ & H 48 & LW1557 & Barnstable & Mass. & 41.69541 & -70.61882 & 12.86 & 13.03 & 0.17 \\
\hline $11 / 19 / 2012$ & A 18 & LW0745 & Washington & R.I. & 41.37750 & -71.83145 & 11.49 & 11.58 & 0.09 \\
\hline 11/19/2012 & 498 & LW0225 & Newport & R.I. & 41.62559 & -71.21990 & 7.92 & 8.05 & 0.13 \\
\hline $11 / 20 / 2012$ & 498 & LW0225 & Newport & R.I. & 41.62559 & -71.21990 & 7.89 & 8.05 & 0.16 \\
\hline $11 / 20 / 2012$ & B 43 & LW1549 & Plymouth & Mass. & 41.98768 & -70.70826 & 13.34 & 13.52 & 0.18 \\
\hline $11 / 27 / 2012$ & M 45 & LW1497 & Plymouth & Mass. & 41.88291 & -70.90829 & 59.89 & 60.01 & 0.12 \\
\hline $12 / 11 / 2012$ & M 45 & LW1497 & Plymouth & Mass. & 41.88291 & -70.90829 & 59.85 & 60.01 & 0.16 \\
\hline $12 / 18 / 2013$ & EP 013 & LW5304 & Providence & R.I. & 41.78601 & -71.33368 & 22.58 & 22.74 & 0.16 \\
\hline 12/19/2013 & W 35 & LX0119 & New London & Conn. & 41.29389 & -72.26556 & 65.67 & 65.78 & 0.11 \\
\hline $12 / 20 / 2013$ & ЕР 013 & LW5304 & Providence & R.I. & 41.78601 & -71.33368 & 22.63 & 22.74 & 0.11 \\
\hline $12 / 20 / 2013$ & S 86 & LX3291 & Hartford & Conn. & 41.76111 & -72.64528 & 30.58 & 30.64 & 0.06 \\
\hline $12 / 23 / 2013$ & B 30 & LW0316 & Providence & R.I. & 41.89913 & -71.38976 & 64.66 & 64.77 & 0.11 \\
\hline $12 / 23 / 2013$ & YY 37 & LW0726 & New London & Conn. & 41.34897 & -71.91281 & 12.55 & 12.64 & 0.09 \\
\hline $12 / 26 / 2013$ & EP 013 & LW5304 & Providence & R.I. & 41.78601 & -71.33368 & 22.59 & 22.74 & 0.15 \\
\hline
\end{tabular}


Table 2. Quality assurance of survey equipment used by the U.S. Geological Survey to determine positions of high-water marks from Hurricane Sandy relative to National Geodetic Survey benchmarks in and near the coastal regions of Connecticut, Rhode Island, and Massachusetts from October to December 2012, December 2013 to June 2014, and December 2016. - Continued

[NGS, National Geodetic Survey; PID, permanent identification; NAD 83, North American Datum of 1983; NAVD 88, North American Vertical Datum of 1988; $\mathrm{ft}$, foot; - , no data]

\begin{tabular}{|c|c|c|c|c|c|c|c|c|c|}
\hline \multirow[b]{2}{*}{ Date } & \multicolumn{2}{|l|}{ NGS benchmark ${ }^{1}$} & \multirow[b]{2}{*}{ County } & \multirow[b]{2}{*}{ State } & \multicolumn{2}{|c|}{ Surveyed, in NAD $83^{2}$} & \multirow{2}{*}{$\begin{array}{c}\text { Surveyed } \\
\text { elevation, } \\
\text { in } \mathrm{ft} \text { above } \\
\text { NAVD } 88\end{array}$} & \multirow{2}{*}{$\begin{array}{c}\text { NGS } \\
\text { benchmark, } \\
\text { NAVD } 88 \\
\text { adjusted } \\
\text { elevation, } \\
\text { in } \mathrm{ft}^{1}\end{array}$} & \multirow{2}{*}{$\begin{array}{c}\text { Difference } \\
\text { between } \\
\text { NGS and } \\
\text { surveyed } \\
\text { elevations, } \\
\text { in } \mathrm{ft}\end{array}$} \\
\hline & $\begin{array}{c}\text { Designation } \\
\text { (stamped name) }\end{array}$ & PID & & & $\begin{array}{c}\text { Latitude, } \\
\text { in decimal } \\
\text { degrees }\end{array}$ & $\begin{array}{c}\text { Longitude, } \\
\text { in decimal } \\
\text { degrees }\end{array}$ & & & \\
\hline $1 / 7 / 2014$ & W 35 & LX0119 & New London & Conn. & 41.29389 & -72.26556 & 65.69 & 65.78 & 0.09 \\
\hline $1 / 10 / 2014$ & S 86 & LX3291 & Hartford & Conn. & 41.76111 & -72.64528 & 30.46 & 30.64 & 0.18 \\
\hline $1 / 13 / 2014$ & S 86 & LX3291 & Hartford & Conn. & 41.76111 & -72.64528 & 30.48 & 30.64 & 0.16 \\
\hline $1 / 17 / 2014$ & S 86 & LX3291 & Hartford & Conn. & 41.76111 & -72.64528 & 30.51 & 30.64 & 0.13 \\
\hline $1 / 24 / 2014$ & D 33 & LX0811 & Fairfield & Conn. & 41.12333 & -73.34583 & 38.47 & 38.43 & -0.04 \\
\hline $1 / 29 / 2014$ & V 92 & LX3458 & New London & Conn. & 41.36667 & -72.20611 & 48.54 & 48.57 & 0.03 \\
\hline $1 / 30 / 2014$ & D 33 & LX0811 & Fairfield & Conn. & 41.12333 & -73.34583 & 38.40 & 38.43 & 0.03 \\
\hline $4 / 14 / 2014$ & S 18 & LW0767 & Washington & R.I. & 41.43297 & -71.69409 & 49.27 & 49.43 & 0.16 \\
\hline $4 / 16 / 2014$ & 498 & LW0225 & Newport & R.I. & 41.62559 & -71.21990 & 7.87 & 8.05 & 0.18 \\
\hline $4 / 17 / 2014$ & CHATHAM LIGHT USCG & AB2629 & Barnstable & Mass. & 41.67174 & -69.94916 & 40.17 & 40.30 & 0.13 \\
\hline $4 / 18 / 2014$ & H 48 & LW1557 & Barnstable & Mass. & 41.69541 & -70.61882 & 12.85 & 13.03 & 0.18 \\
\hline $4 / 28 / 2014$ & 8450768 TIDAL 1 & LW0620 & Newport & R.I. & 41.46537 & -71.19186 & 6.04 & 5.99 & -0.05 \\
\hline $4 / 29 / 2014$ & H 48 & LW1557 & Barnstable & Mass. & 41.69541 & -70.61882 & 12.88 & 13.03 & 0.15 \\
\hline $6 / 12 / 2014$ & $\mathrm{H} 48$ & LW1557 & Barnstable & Mass. & 41.69541 & -70.61882 & 12.82 & 13.03 & 0.21 \\
\hline 6/13/2014 & CHATHAM LIGHT USCG & AB2629 & Barnstable & Mass. & 41.67174 & -69.94916 & 40.20 & 40.30 & 0.10 \\
\hline $12 / 28 / 2016$ & TRI STA & MY0588 & Suffolk & Mass. & 42.37366 & -71.05356 & 8.81 & 8.85 & 0.04 \\
\hline
\end{tabular}

${ }^{1}$ National Oceanic and Atmospheric Administration (2012c).

${ }^{2}$ Coordinates are from the original horizontal survey in World Geodetic System of 1984; transformation to NAD 83 resulted in negligible differences.

${ }^{3}$ Not an NGS benchmark.

${ }^{4}$ Benchmark is a tidal benchmark that is measured in low mean sea level instead of NAVD 88. 
Table 3. Summary of high-water marks flagged and surveyed in coastal areas of Connecticut, Rhode Island, and Massachusetts following Hurricane Sandy in October 2012.

[NAVD 88; North American Vertical Datum of 1988; USGS, U.S. Geological Survey]

\begin{tabular}{|c|c|c|c|c|c|c|c|c|}
\hline \multirow[b]{2}{*}{ State and county } & \multicolumn{2}{|c|}{ High-water mark' } & \multicolumn{6}{|c|}{ Elevation, in feet NAVD 88} \\
\hline & $\begin{array}{l}\text { Number } \\
\text { flagged }\end{array}$ & $\begin{array}{l}\text { Number } \\
\text { surveyed }\end{array}$ & Minimum & Maximum & Median & Average & 25th percentile & 75th percentile \\
\hline Fairfield & 55 & 53 & 5.1 & 12.2 & 9.9 & 9.7 & 9.2 & 10.2 \\
\hline Middlesex & 20 & 19 & 6.6 & 8.8 & 7.1 & 7.3 & 7.0 & 7.5 \\
\hline New London & 36 & 34 & 4.8 & 10.1 & 5.9 & 6.1 & 5.7 & 6.4 \\
\hline Statewide & 162 & 157 & 2.5 & 12.2 & 8.3 & 8.1 & 6.8 & 9.6 \\
\hline \multicolumn{9}{|c|}{ Rhode Island } \\
\hline Bristol & 6 & 6 & 6.2 & 7.0 & 6.6 & 6.6 & 6.3 & 6.9 \\
\hline Kent & 5 & 5 & 6.2 & 7.0 & 6.6 & 6.6 & 6.5 & 6.9 \\
\hline Washington & 42 & 42 & 3.9 & 16.2 & 6.5 & 7.1 & 5.7 & 8.4 \\
\hline Statewide & 77 & 76 & 3.6 & 16.2 & 6.6 & 7.1 & 6.1 & 8.2 \\
\hline \multicolumn{9}{|c|}{ Massachusetts } \\
\hline Barnstable & 46 & 45 & 2.8 & 19.2 & 5.1 & 5.8 & 4.0 & 6.9 \\
\hline Bristol & 13 & 13 & 4.2 & 7.7 & 5.0 & 6.1 & 5.5 & 6.7 \\
\hline Dukes & 9 & 9 & 3.8 & 7.0 & 5.0 & 5.3 & 4.2 & 6.2 \\
\hline Essex & 21 & 21 & 5.7 & 16.8 & 7.9 & 8.4 & 6.1 & 9.2 \\
\hline Middlesex & 1 & 1 & 5.6 & 5.6 & 5.6 & 5.6 & 5.6 & 5.6 \\
\hline Nantucket & 10 & 10 & 3.3 & 16.0 & 9.1 & 8.8 & 4.6 & 11.8 \\
\hline \multicolumn{9}{|c|}{ All three States } \\
\hline Total & 371 & 364 & 2.5 & 22.7 & 7.2 & 7.6 & 5.8 & 9.1 \\
\hline
\end{tabular}

${ }^{1}$ Information on the location, type, accuracy, and elevation of individual high-water marks is available in Bent (2018) and on the USGS Flood Event Viewer website for Hurricane Sandy (https://stn.wim.usgs.gov/fev/\#Sandy). 
The HWM elevations along eastern Massachusetts were slightly higher than along the southern coastline of Rhode Island and Massachusetts (fig. 2B). The median HWM elevations for Plymouth, Norfolk, and Essex Counties were 7.7, 7.3, and $7.9 \mathrm{ft}$, respectively, compared with the median elevations of Bristol and Barnstable Counties along the southern coast of Massachusetts and of Newport and Washington Counties in Rhode Island. This may be because of the prevailing westerly wind directions on October 29 (Blake and others, 2013, fig. 17). The median HWM elevation of $5.6 \mathrm{ft}$ for Middlesex County was likely lower than the other three counties in eastern Massachusetts because the county is somewhat shielded by the Boston Harbor Islands.

In all three States (fig. 2), the lowest HWM elevations were found at sites generally farthest inland from the Atlantic Ocean. These sites were not openly exposed to the oncoming direction of winds and waves. The highest HWM elevation values were seen on coastline areas, such as extended beaches, which had direct exposure to contact waves and wave run up. These areas may also be open to large areas of great wind fetch off the ocean. In several cases, increased elevations were seen where the surge funneled or piled up into a narrowing bay or estuary where the tides could not quickly drain with the continued winds and tide surges built on one another.

The HWM elevations in the three States compared well with the recorded peak tide elevations recorded at the 58 USGS temporary storm tide sensors (another sensor was not found or destroyed) and 2 real-time rapid deployment gages installed before Hurricane Sandy (McCallum and others, 2013). Although the 56 temporary storm tide sensors and 2 rapid deployment gages that recorded the peak storm tides is far less in number than the 364 HWMs surveyed along the coast of Connecticut, Rhode Island, and Massachusetts, the ranges, averages, and median elevations are similar. For example, in Connecticut, Rhode Island, and Massachusetts, average recorded peak storm tides were 8.3,6.3, and $6.2 \mathrm{ft}$, respectively (McCallum and others, 2013, table 3). Any slight differences in storm tide elevations are likely because of the sample size difference between 58 temporary sensor and 2 rapid deployment gage elevations and the 364 HWM elevations.

\section{Uses of Data}

This report documents storm tides in the coastal areas of Connecticut, Rhode Island, and Massachusetts from Hurricane Sandy. The location and elevation of the HWMs used to measure the storm tides resulting have been documented along nearly $3,078 \mathrm{mi}$ of coastline in southern New England. These data are needed by emergency managers to delineate areas likely to be flooded and to evaluate the extent of such flooding, as well as by other Federal, State, and local government agencies, nongovernmental organizations, universities, and the public for land-use planning, flood risk, flood resiliency, and coastal modeling. These entities use these data to make more informed decisions regarding the management and development of areas shown to be affected by ocean storms within the coastal environment.

\section{Summary}

On October 27-29, 2012, Hurricane Sandy moved up the eastern coast of the United States after passing over the Bahamas. On October 29, 2012, at about 7:30 p.m. eastern daylight time, Hurricane Sandy, with wind speeds of about $80 \mathrm{mi} / \mathrm{hr}$, made landfall near Brigantine, New Jersey. Hurricane Sandy resulted in 147 deaths, about 650,000 homes and many businesses being damaged along the eastern coast of the United States, and more than $\$ 50$ billion in damages, making it the second most costly Atlantic hurricane at that time following Hurricane Katrina in 2005. Because of the large extent of damages caused by Hurricane Sandy's high winds and storm tides and surge, a presidential disaster was declared for 10 northeastern States and the District of Columbia in the months following Hurricane Sandy, including Connecticut, Rhode Island, and Massachusetts. To document the peak storm tides from Hurricane Sandy along the coastal areas from Virginia to Massachusetts, the Federal Emergency Management Agency (FEMA) authorized a mission assignment for the U.S. Geological Survey (USGS) to identify, flag, and survey high-water marks (HWMs) following Hurricane Sandy in late October 2012. Although Connecticut, Rhode Island, and Massachusetts were not struck directly by Hurricane Sandy, storm tides affected the coastal areas of all three States.

In response to the approach of Hurricane Sandy, the USGS deployed 60 temporary storm tide sensors and 2 temporary real-time rapid deployment gages to collect tide elevation data during the storm along the coastal areas of Connecticut, Rhode Island, and Massachusetts. This activity was done from Virginia to Maine before the storm. Following Hurricane Sandy, in October and November 2012, 371 HWMs from storm tides associated with Hurricane Sandy were identified and flagged in coastal areas at of Connecticut (162 sites), Rhode Island (77 sites), and Massachusetts (132 sites). Those HWMs near USGS temporary storm tide sensors, real-time rapid deployment gages, and streamgages (affected by the storm tide) and on Block Island, Rhode Island, and Martha's Vineyard and Nantucket, Massachusetts, were surveyed to record the elevation at the time the HWMs were identified and flagged in October and November 2012. Survey crews recorded information including the HWM's physical description, horizontal location (latitude and longitude), rating of accuracy, and a description and sketch of the location and the type of HWM left for future surveys on field forms. In addition, photographs were taken of each HWM and the 
area so the HWM could be successfully located in future surveys. The remaining HWMs flagged during October and November 2012 were surveyed from December 2013 through June 2014 and in December 2016. Elevations of all HWMs were referenced to the North American Vertical Datum of 1988 (NAVD 88), and horizontal coordinates, to the North American Datum of 1983, using the Global Navigation Satellite System, survey-grade Global Positioning System (GPS) receivers, and total station surveying equipment. Continuous real-time differential corrections to the GPS positions and elevations were made using a proprietary fixedbase station GPS network of receivers. The GPS elevations were checked for quality assurance against 26 National Geodetic Survey benchmarks and 1 other benchmark with established NAVD 88 elevations near the coast of Connecticut, Rhode Island, and Massachusetts. For the 49 qualityassurance observations, the absolute differences between the GPS elevations and established NAVD 88 elevations had an average of 0.15 foot (ft), a median of $0.13 \mathrm{ft}$, and a root mean square error of $0.1884 \mathrm{ft}$.

Of the 371 HWMs identified and flagged following Hurricane Sandy, 7 could not be found during the surveying. The 157 HWMs surveyed in Connecticut had elevations that ranged from 2.5 to $12.2 \mathrm{ft}$, with an average of $8.1 \mathrm{ft}$ and a median of $8.3 \mathrm{ft}$. The $76 \mathrm{HWMs}$ surveyed in Rhode Island had elevations that ranged from 3.6 to $16.2 \mathrm{ft}$, with an average of $7.1 \mathrm{ft}$ and a median of $6.6 \mathrm{ft}$. The $131 \mathrm{HWMs}$ surveyed in Massachusetts had elevations that ranged from 2.8 to $22.7 \mathrm{ft}$, with an average of $7.3 \mathrm{ft}$ and a median of $6.6 \mathrm{ft}$. Individual information on the location, type, accuracy, and elevation of the 371 HWMs can be found in an accompanying USGS data release and at the USGS Flood Event Viewer website for Hurricane Sandy.

The HWMs along the Connecticut and eastern Massachusetts including Nantucket coastline generally had higher storm tide elevations than the coastline of Rhode Island (including Block Island) and southern Massachusetts (including Martha's Vineyard). The HWM elevations compare well with recorded peak-storm tide data at USGS temporary storm tide sensors and real-time rapid deployment gages deployed for Hurricane Sandy in Connecticut, Rhode Island, and Massachusetts.

Data collected following Hurricane Sandy can be used by Federal, State, and local government agencies, nongovernmental organizations, universities, and the public in understanding the areal extent and depth of the storm tides. Additionally, these data can be used for land-use planning, flood risk studies, flood resiliency studies, and coastal models. The data from this historic storm can be compared with data from past and future regional hurricanes and tropical storms to assist in future planning and preparedness.

\section{References Cited}

Benson, M.A., and Dalrymple, T., 1967, General field and office procedures for indirect measurements: U.S. Geological Survey Techniques of Water-Resources Investigations, book 3, chap. Al, 30 p., accessed July 22, 2015, at http://pubs.er.usgs.gov/publication/twri03A1.

Bent, G.C., 2018, High-water mark data from Hurricane Sandy for the coastal areas of Connecticut, Rhode Island, and Massachusetts, October 29-30, 2012: U.S. Geological Survey data release, https://doi.org/10.5066/F7R49Q1C.

Blake, E.S., Kimberlain, T.B., Berg, R.J., Cangialosi, J.P., and Beven, J.L., II, 2013, Tropical cyclone report; Hurricane Sandy (AL182012); 22-29 October 2012: National Oceanic and Atmospheric Administration tropical cyclone report, 157 p., accessed July 10, 2015, at http://www.nhc.noaa.gov/ data/tcr/AL182012_Sandy.pdf.

Federal Emergency Management Agency, 2012, Disaster declarations for 2012: Federal Emergency Management Agency website, accessed July 15, 2015, at https://www.fema.gov/disasters/grid/ year/2012?field_disaster_type_term_tid_1=All.

Federal Emergency Management Agency, 2018, Sandy five years later: Federal Emergency Management Agency website, accessed June 9, 2018, at https://www.fema.gov/ sandy-recovery-office.

KeyNetGPS, Inc., 2013, A Trimble VRS network: KeyNetGPS, Inc. website, accessed February 13, 2013, at http://vrs.keynetgps.com/Map/SensorMap.aspx.

Knabb, R.D., Rhome, J.J., and Brown, D.P., 2005, Tropical cyclone report; Hurricane Katrina; 23-30 August 2005: National Oceanic and Atmospheric Administration tropical cyclone report, 13 p., accessed June 30, 2016, at http://www.nhc.noaa.gov/data/tcr/AL122005_Katrina.pdf.

Lumia, R., Burke, P.M., and Johnston, W.H., 1987, Flooding of December 29, 1984, through January 2, 1985, in northern New York State, with flood profiles of the Black and Salmon Rivers: U.S. Geological Survey Water-Resources Investigations Report 86-4191, 53 p. [Also available at https://pubs.er.usgs.gov/publication/wri864191.]

Massachusetts Executive Office of Public Safety and Security, 2015, New England hurricanes of note: Massachusetts Executive Office of Public Safety and Security website, accessed September 20, 2015, at $\mathrm{http} / / / \mathrm{mgcm} t r a i n i n g . m a s s . g o v /$ eopss/agencies/mema/ hazards/hurricanes/new-england-hurricanes-of-note.html. 
McCallum, B.E., Wicklein, S.M., Reiser, R.G., Busciolano, R., Morrison, J., Verdi, R.J., Painter, J.A., Frantz, E.R., and Gotvald, A.J., 2013, Monitoring storm tide and flooding from Hurricane Sandy along the Atlantic coast of the United States, October 2012: U.S. Geological Survey Open-File Report 2013-1043, 42 p., accessed May 1, 2013, at https://pubs.er.usgs.gov/publication/ofr20131043.

National Atmospheric and Space Administration, 2012, Hurricane Sandy off the Carolinas: Earth Observatory Images website, accessed June 30, 2016 at https://earthobservatory.nasa.gov/NaturalHazards/ view php?id=79548.

National Atmospheric and Space Administration, 2013, Hurricane Sandy (Atlantic Ocean): National Atmospheric and Space Administration hurricanes website, accessed July 28, 2015, at http://www.nasa.gov/mission_pages/hurricanes/ archives/2012/h2012_Sandy.html.

National Oceanic and Atmospheric Administration, 2012a, Bridgeport, Conn., station 8467150, tide/ water levels for October 26 to November 3, 2012: National Oceanic and Atmospheric Administration tides and currents website, accessed June 11, 2018, at https://idesandcurrents.noaa.gov/waterlevels.html?id $=8467150 \&$ units $=$ standard $\&$ bdate $=20121026 \&$ edate $=20121103 \&$ timezone $=$ GMT \& datum $=$ MHHW \&interval $=\mathrm{h}$ \&action $=$.
National Oceanic and Atmospheric Administration, 2012b, Storm data and unusual weather phenomena with late reports and corrections, October 2012, v. 54, no. 10: National Oceanic and Atmospheric Administration, 124 p., accessed July 28, 2015, at https:/www.ncdc.noaa.gov/IPS/ $\mathrm{sd} / \mathrm{sd}$.html.

National Oceanic and Atmospheric Administration, 2012c, Survey marks and datasheets: National Geodetic Survey website, accessed October 30, 2012, at https://www.ngs.noaa.gov/datasheets/index.shtml.

National Oceanic and Atmospheric Administration, 2013, Hurricane/post-Tropical Cyclone Sandy, October 22-29, 2012: National Oceanic and Atmospheric Administration service assessment, [variously paged], accessed May 28, 2015, at https://www.weather.gov/media/publications/assessments/ Sandy13.pdf.

Rydlund, P.H., Jr., and Densmore, B.K., 2012, Methods of practice and guidelines for using survey-grade global navigation satellite systems (GNSS) to establish vertical datum in the United States Geological Survey: U.S. Geological Survey Techniques and Methods, book 11, chap. D1, 102 p., accessed December 24, 2013, at http://pubs.usgs.gov/ tm/11d1/tm11-D1.pdf.

U.S. Geological Survey, 2018, STN flood event data download: U.S. Geological Survey Short-Term Network website, accessed June 9, 2018, at https://stn.wim.usgs.gov/ STNDataPortal/\#. 
For more information about this report, contact: Director, New England Water Science Center U.S. Geological Survey

10 Bearfoot Road

Northborough, MA 01532

dc_nweng@usgs.gov

or visit our website at

https://newengland.water.usgs.gov

Publishing support provided by the Pembroke Publishing Service Center 


\section{总}

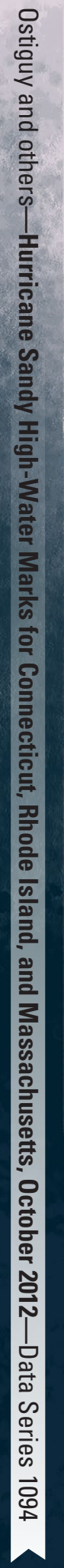

